\title{
Determination of Radiological Hazard Associated with the use of Imayan River Sediment as Building Material
}

\author{
${ }^{* 1}$ SOWOLE O
}

\author{
Department of Physics and Telecommunication, \\ Tai Solarin University of Education, Ijagun, Ijebu-Ode, Ogun State, Nigeria \\ Email:segunsowole@yahoo.com \\ Telephone: +2348023531317
}

\begin{abstract}
The radioactivity concentrations of ${ }^{40} \mathrm{~K},{ }^{238} \mathrm{U}$ and ${ }^{232} \mathrm{Th}$ in sediment samples of Imayan river at Odogbolu local government area, Ogun State in Nigeria were determined by gamma spectrometry using NaI (TI) detector coupled with a pre-amplifier base to a multiple channel analyzer (MCA), these were then used to determine the radiological indicators; radium equivalent activity, internal and external hazard indices, and absorbed dose rate which translated to the annual effective dose rate. 10 sediment samples were collected from the river. The highest radioactivity concentrations of ${ }^{40} \mathrm{~K},{ }^{238} \mathrm{U}$ and ${ }^{232} \mathrm{Th}$ obtained from the sediment samples were $110.34 \pm 10.68 \mathrm{Bqkg}^{-1}, 9.02 \pm 3.16 \mathrm{Bqkg}^{-1}$ and $11.56 \pm 4.23 \mathrm{Bqkg}^{-1}$ respectively. The mean external hazard index $\left(\mathrm{H}_{\mathrm{ex}}\right)$ and mean internal hazard index $\left(\mathrm{H}_{\mathrm{in}}\right)$ for all the sediment samples were calculated to be $0.066 \mathrm{Bqkg}^{-}$ ${ }^{1}$ and $0.081 \mathrm{Bqkg}^{-1}$ respectively, while the mean radium equivalent activity was obtained to be $24.62 \mathrm{Bqkg}^{-1}$. Absorbed dose rate mean value was calculated to be $17.41 \mathrm{nGyhr}^{-1}$ with mean annual effective dose rate of $0.022 \mathrm{mSvyr}^{-1}$ The values of the radiological indicators were found to be within the limits recommended for safety, indicating that the use of the sediment of the river as building material does not have radiological health hazards to the occupants of the buildings. OJASEM
\end{abstract}

KEYWORDS: Concentration, radionuclide, radiological indicators, absorbed dose rate

\section{http://dx.doi.org/10.4314/jasem.v19i1.8}

\section{Introduction}

The world is naturally radioactive, thereby exposing humans to naturally occurring quantities of radiation on a daily basis. The exposure of human beings to ionizing radiation from natural sources is a continuing and inescapable feature of life on earth. For most individuals, this exposure exceeds that from all man-made sources combined (UNSCEAR, 2000). Radionuclides are chemical elements with unstable atomic structures called radioactive isotopes. In many parts of the world, building materials containing radioactive materials have been used for generations. As individuals spend more than $80 \%$ of their time indoor, the internal and external radiation exposure from building materials creates prolonged exposure situation (ICRP, 1999). Radiation being energy emitted when a radionuclide decays. It can affect living tissue only when the energy is absorbed in that tissue. Radionuclides can be hazardous to living tissue when they are inside an organism where radiation released can be immediately absorbed. They may also be hazardous when they are outside of the organism but close enough for some radiation to be absorbed by the tissue. Radionuclides can be released into the air by human activities. They can also be created in the atmosphere by natural processes such as the interaction of cosmic radiation with nitrogen to produce radioactive Carbon-14. Radionuclides can be removed from the air in several ways. Particles settle out of the atmosphere if air currents cannot keep them suspended. Rain or snow can also remove them. When these particles are removed from the atmosphere; they may land in water, on soil, or on the surfaces of living and non-living things. The particles may return to the atmosphere by re-suspension, which occurs when wind or some other natural or human activity generates clouds of dust containing radionuclides (OEPA, 2005). The main external source of irradiation to the human body is represented by the gamma radiation emitted by naturally occurring radioisotopes, also called terrestrial environmental radiation. These radioisotopes, such as ${ }^{40} \mathrm{~K}$ and the radionuclides from the ${ }^{232} \mathrm{Th}$ and ${ }^{238} \mathrm{U}$ series and their decay products, exist at trace levels in all ground formations. Therefore, natural environmental radioactivity and the associated external exposure due to gamma radiation depend primarily on the geological and geographical conditions, and appear at different levels in the soils of each different geological region 
(UNSCEAR, 1993; 2000). However, it has been observed that the type and concentration vary considerably depending on the soil type. The effects of the radiation emitted by different radionuclides depend on the overlining soil material (thickness and type), its chelating agents and physio-chemical properties (Believermis et al, 2009). The exposure of man to gamma radiation from these radionuclides in the aquatic environment is not limited to the internal exposure due to ingestion through the consumption of contaminated aquatic foods. The use of river sediments as a constituent of building materials for flooring, plastering and in moulding bricks in the coastal areas of Nigeria has the probability of increasing the external exposure level to man if such sediments have high concentration of radionuclides (Oni et al, 2011).

This research work is to evaluate radiological hazards associated with the use of Imayan river sediment as building material to occupants.

\section{MATERIALS AND METHODS}

Total of ten (10) samples of Imayan river sediments at Odogbolu local government area in Ogun State were collected at distance of $50-100 \mathrm{~m}$ apart. Sediment samples were collected from the bottom of the river by the help of local divers. The collected sediment samples were kept in clean polythene bags and labelled.

The samples were all oven dried at $80^{\circ} \mathrm{C}$, to remove moisture, which otherwise would result in self absorption of the radionuclides during radio assay. The sediment samples were sieved after pulverization, packed $120.0 \mathrm{~g}$ in plastic containers of base diameter $5.0 \mathrm{~cm}$ so as to sit comfortably on the $\mathrm{NaI}(\mathrm{Tl})$ detector of diameter $5.1 \mathrm{~cm}$ used in this work. The samples were all sealed and kept for 28 days in order to obtain secular equilibrium between radioactive daughter nuclides and their respective progenies.

The method of gamma spectrometry was adopted for the analysis of the samples collected in order to obtain data on ${ }^{40} \mathrm{~K},{ }^{238} \mathrm{U}$ and ${ }^{232} \mathrm{Th}$. The spectrometer used was a Canberra lead shielded $7.6 \mathrm{~cm} \times 7.6 \mathrm{~cm}$ $\mathrm{NaI}(\mathrm{Tl})$ detector coupled to a multichannel analyzer (MCA) through a preamplifier base. The resolution of the detector is about $10 \%$ at $0.662 \mathrm{MeV}$ of $137 \mathrm{Cs}$. According to Jibiri and Farai (1998) the value is good enough for $\mathrm{NaI}$ detector to distinguish the gamma ray energies of most radionuclides in samples. For the analyses of ${ }^{40} \mathrm{~K},{ }^{238} \mathrm{U}$ and ${ }^{232} \mathrm{Th}$, the photo peak regions of ${ }^{40} \mathrm{~K}(1.46 \mathrm{MeV}),{ }^{214} \mathrm{Bi}(1.76 \mathrm{MeV})$ and ${ }^{208} \mathrm{TI}(2.615 \mathrm{MeV})$ were respectively used. The cylindrical plastic containers holding the samples were put to sit on the high geometry $7.6 \mathrm{~cm} \times 7.6 \mathrm{~cm}$ $\mathrm{NaI}$ (TI) detector. High level shielding against the environmental background radiation was achieved by counting in a Canberra $10 \mathrm{~cm}$ thick lead castle. The counting of each sample was done for $10 \mathrm{hrs}$ because of suspected low activities of the radionuclides in the samples. The areas under the photo-peaks of ${ }^{40} \mathrm{~K}$, ${ }^{238} \mathrm{U}$ and ${ }^{232} \mathrm{Th}$ were computed using the Multichannel Analyzer system.

Theoretical Consideration and Calculations: The concentrations of the radionuclides were calculated based on the measured efficiency of the detector and the net count rate under each photopeak over a period of 10 hours using equation 1.0

$\mathrm{C}=\frac{N\left(E_{\gamma}\right)}{\varepsilon\left(E_{\gamma}\right) I_{\gamma} M t_{c}} \quad 1.0$

Where: $\mathrm{N}\left(\mathrm{E}_{\gamma}\right)=$ Net peak area of the radionuclide of interest, $\varepsilon\left(\mathrm{E}_{\gamma}\right)=$ Efficiency of the detector for the $\gamma$ energy of interest, $\mathrm{I}_{\gamma}=$ Intensity per decay for the $\gamma$ energy of interest, $\mathrm{M}=$ Mass of the sample, $\mathrm{t}_{\mathrm{c}}=$ Total counting time in seconds (36000s). The radiological indicators are radium equivalent activity $\left(\mathrm{Ra}_{\mathrm{eq}}\right)$, internal hazard index $\left(\mathrm{H}_{\text {in }}\right)$ and external hazard index $\left(\mathrm{H}_{\mathrm{ex}}\right)$. These were used to estimate the radiological implications of the use of the sediment samples from the river as building material to man. The $\mathrm{Ra}_{\mathrm{eq}}$ was calculated by the equation described by Bereka et al (1985) and Yang et al (2005) as indicated by equation 2.0

$\mathrm{Ra}_{\mathrm{eq}}=\frac{10}{130} \mathrm{C}_{\mathrm{k}}+\frac{10}{7} \mathrm{C}_{\mathrm{Th}}+\mathrm{C}_{\mathrm{Ra}} \quad 2.0$

Where $\mathrm{C}_{\mathrm{Ra}}, \mathrm{C}_{\mathrm{Th}}$ and $\mathrm{C}_{\mathrm{K}}$ were the activity concentrations in $\mathrm{Bqkg}^{-1}$ of ${ }^{226} \mathrm{Ra},{ }^{232} \mathrm{Th}$ and ${ }^{40} \mathrm{~K}$ respectively. The external hazard index $\left(\mathrm{H}_{\mathrm{ex}}\right)$ commonly used to evaluate the indoor radiation dose rate due to external exposure to gamma radiation from natural radionuclides in building materials as reported by Hamzah et al (2008) was presented in equation 3.0.

$\mathrm{H}_{\mathrm{ex}}=\frac{C_{k}}{4810}+\frac{C_{T h}}{259}+\frac{C_{R a}}{370} \leq 1 \quad 3.0$

The internal hazard index $\left(\mathrm{H}_{\text {in }}\right)$ is a parameter for estimating the negative effect of radioactive materials on lungs and other respiratory organ. The risk internal exposure due to the natural radionuclides ${ }^{40} \mathrm{~K},{ }^{226} \mathrm{Ra}$ and ${ }^{232} \mathrm{Th}$ can be assessed from the value of $\mathrm{H}_{\text {in }}$ using the equation:

\section{${ }^{*}$ SOWOLE $O$}


$\mathrm{H}_{\mathrm{in}}=\frac{C_{k}}{4810}+\frac{C_{T h}}{259}+\frac{C_{R a}}{185} \leq 14.0$

where $\mathrm{C}_{\mathrm{k}}, \mathrm{C}_{\mathrm{Th}}$ and $\mathrm{C}_{\mathrm{Ra}}$ were the concentrations of ${ }^{40} \mathrm{~K},{ }^{226} \mathrm{Ra}$ and ${ }^{232} \mathrm{Th}$ respectively.

In addition, considering the definition of the absorbed dose rate in indoor air $\mathrm{D}(\mathrm{nGy} / \mathrm{h})$ given by UNSCEAR (1993), EC (1999) and Papastefanou et al (2005) from the natural radionuclides as: $\mathrm{D}(\mathrm{nGy} / \mathrm{hr})=$ $0.080 \mathrm{C}_{\mathrm{k}}+1.1 \mathrm{C}_{\mathrm{Th}}+0.92 \mathrm{C}_{\mathrm{Ra}} \quad 5.0$

\section{RESULTS AND DISCUSSION}

The radioactivity concentrations of natural radionuclides obtained from the sediments of Imayan river are shown in table 1 . The lowest concentration
The absorbed dose rate in air translates to the annual effective dose rate indoor for individuals using the values of the absorbed dose rate in indoor air, $\mathrm{D}(\mathrm{nGy} / \mathrm{hr})$, the effective dose conversion factor taken

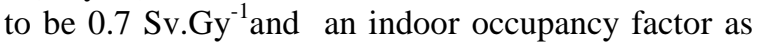
0.8 with the annual occupancy time approximately $7000 \mathrm{~h} / \mathrm{yr}$. Hence the annual effective dose rate is estimated as: $\mathrm{A}_{\mathrm{E}}(\mathrm{mSv} / \mathrm{yr})=\mathrm{D}(\mathrm{nGy} / \mathrm{hr})$ x $7000(\mathrm{hr} / \mathrm{yr})$ x $0.7(\mathrm{~Sv} / \mathrm{Gy}) \times 10^{-6} \quad 6.0$

of ${ }^{40} \mathrm{k}$ was $79.86 \pm 5.02 \mathrm{Bqkg}^{-1}$ and the highest was $110.34 \pm 10.68 \mathrm{Bqkg}^{-1}$. For ${ }^{238} \mathrm{U}$, the lowest concentration was $2.25 \pm 1.06 \mathrm{Bqkg}^{-}$

Table 1: Concentrations of natural radionuclides in Imayan river sediment samples

\begin{tabular}{|c|c|c|c|c|}
\hline \multirow{2}{*}{ River } & \multirow{2}{*}{ Sample } & \multicolumn{3}{|c|}{$\begin{array}{l}\text { Radioactivity concentrations } \\
\text { of sediment samples }\left(\mathrm{bqkg}^{-1}\right)\end{array}$} \\
\hline & & ${ }^{40} \mathrm{~K}$ & ${ }^{238} \mathbf{U}$ & ${ }^{232} \mathrm{Th}$ \\
\hline \multirow{10}{*}{ Imayan } & $\mathrm{S}_{1}$ & $105.62 \pm 9.25$ & $9.02 \pm 3.16$ & $11.34 \pm 4.18$ \\
\hline & $\mathrm{S}_{2}$ & $82.75 \pm 5.12$ & $2.87 \pm 1.24$ & $8.36 \pm 2.25$ \\
\hline & $\mathrm{S}_{3}$ & $98.16 \pm 6.25$ & $5.24 \pm 2.32$ & $9.46 \pm 3.12$ \\
\hline & $\mathrm{S}_{4}$ & $110.34 \pm 10.68$ & $3.85 \pm 1.76$ & $7.78 \pm 2.04$ \\
\hline & $\mathrm{S}_{5}$ & $95.27 \pm 5.82$ & $7.16 \pm 2.83$ & $11.56 \pm 4.23$ \\
\hline & $\mathrm{S}_{6}$ & $79.86 \pm 5.02$ & $6.26 \pm 2.41$ & $4.26 \pm 0.85$ \\
\hline & $\mathrm{S}_{7}$ & $97.24 \pm 6.14$ & $5.64 \pm 2.38$ & $7.47 \pm 1.92$ \\
\hline & $\mathrm{S}_{8}$ & $108.05 \pm 9.66$ & $2.25 \pm 1.06$ & $5.08 \pm 1.24$ \\
\hline & $\mathrm{S}_{9}$ & $102.89 \pm 8.84$ & $6.18 \pm 2.27$ & $9.18 \pm 2.97$ \\
\hline & $S_{10}$ & $87.36 \pm 5.32$ & $4.88 \pm 1.95$ & $8.42 \pm 2.36$ \\
\hline
\end{tabular}

while the highest was $9.02 \pm 3.16 \mathrm{Bqkg}^{-1}$. The lowest concentration of ${ }^{232} \mathrm{Th}$ was $4.26 \pm 0.85 \mathrm{Bqkg}^{-1}$ and the highest was $11.56 \pm 4.23 \mathrm{Bqkg}^{-1}$. Concerning the radium equivalent activity $\left(\mathrm{Ra}_{\mathrm{eq}}\right)$ as shown in table 2 , the lowest value was $17.8 \mathrm{Bqkg}^{-1}, 33.4 \mathrm{Bqkg}^{-1}$ was the highest and the mean value was obtained as 24.62 $\mathrm{Bqkg}^{-1}$. These values are lower than the recommended limit value of $370 \mathrm{~Bq} \cdot \mathrm{kg}^{-1}$ as building material (Matiullah et al, 2004).

Table 2: Determined values of radiological indicators from the sediment samples

\begin{tabular}{cccccc}
\hline Sample & $\begin{array}{c}\mathrm{Ra}_{\mathrm{eq}}(\mathrm{B} \\
\left.\mathrm{q} \cdot \mathrm{kg}^{-1}\right)\end{array}$ & $\mathrm{H}_{\text {in }}\left(\mathrm{Bq}_{\mathrm{kg}}{ }^{-1}\right)$ & $\begin{array}{c}\mathrm{H}_{\mathrm{ex}}(\mathrm{Bq} \cdot \mathrm{kg} \\
-1\end{array}$ & $\begin{array}{c}\mathrm{D}(\mathrm{nGy} \cdot \mathrm{h} \\
\left.{ }^{-1}\right)\end{array}$ & $\mathrm{A}_{\mathrm{E}}\left(\mathrm{mSvy}^{-1}\right)$ \\
\hline $\mathrm{S}_{1}$ & 33.4 & 0.115 & 0.090 & 21.75 & 0.027 \\
$\mathrm{~S}_{2}$ & 21.2 & 0.065 & 0.057 & 16.08 & 0.020 \\
$\mathrm{~S}_{3}$ & 26.3 & 0.085 & 0.071 & 18.47 & 0.023 \\
$\mathrm{~S}_{4}$ & 23.5 & 0.074 & 0.063 & 17.74 & 0.022 \\
$\mathrm{~S}_{5}$ & 31.0 & 0.103 & 0.084 & 21.00 & 0.026 \\
$\mathrm{~S}_{6}$ & 18.5 & 0.067 & 0.045 & 11.65 & 0.014 \\
$\mathrm{~S}_{7}$ & 23.8 & 0.080 & 0.064 & 16.52 & 0.020 \\
$\mathrm{~S}_{8}$ & 17.8 & 0.054 & 0.048 & 14.44 & 0.018 \\
$\mathrm{~S}_{9}$ & 27.2 & 0.090 & 0.074 & 18.90 & 0.023 \\
\hline $\mathrm{S}_{10}$ & 23.6 & 0.077 & 0.063 & 17.50 & 0.022 \\
\hline
\end{tabular}

Also, internal hazard indices ranged from 0.054 to 0.115 with mean value of 0.081 and external hazard indices ranged from 0.045 to 0.090 with mean value of 0.066. All the values are below unity as recommended limit (European Commission, 1999). The absorbed dose rate ranged from $11.65 \mathrm{nGyh}^{-1}$ to 
$21.75 \mathrm{nGyh}^{-1}$ with mean value of $17.41 \mathrm{nGyh}^{-1}$. These are below the worldwide mean of $84.0 \mathrm{nGyh}^{-1}$ (UNSCEAR, 2000), and this translates to the mean annual effective dose rate of $0.022 \mathrm{mSvy}^{-1}$.

Conclusion: The values of radiological indicators from Imayan river sediment samples had been determined using concentration values of natural radionuclides obtained from gamma spectrometry analyses, which were below the recommended values worldwide. Therefore, Imayan river sediment can be used as building material because it poses no radiological health hazard to the occupants

\section{REFERENCES}

Beliverimis M., Kilic O., Coytuk Y. and Topcough S. (2009). The effects of physiochemical properties of gamma emitting natural radionuclides level in the soil profile of Istanbul, Environmental monitoring and assessment 163: 15-16.

Bereka J. and Mathew P.J. (1985). Natural radioactivity of Australian building materials industrial wastes and by-products. Health Phys: Vol.48, No.1, pp.87-95.

European Commission (1999). Radiological Protection Principles concerning the Natural Radioactivity of Building materials, Radiation Protection Report RP-112, Luxembourg.

Hamzah Z., Ahmad S., Noor H. M. and She D. E. (2008) Surface Radiation Dose and Radionuclide Measurement in Ex-Tin Mining Area, Kg Gajah, Perak, The Malaysian Journal of Analytical Sciences, Vol. 12, No. 2, pp. 419431.

International Commission on Radiological Protection (ICRP) (1999). Protection of the public in situations of prolonged radiation exposure, Publication 82.
Jibiri, N.N. and Farai, I.P. (1998) Assessment of Dose Rate and Collective Effective Dose Equivalent due to Terrestrial Gamma Radiation in the city of Lagos, Nigeria. Radiat Prot. Dosim. 76 191-194

Matiullah, A. Ahad, S. Rehman, S. and Faheem M. (2004) Measurement of Radioactivity in Soil of Bahawapur Division, Pakistan, Radiation Protection Dosimetry, Vol. 112, No. 3, pp. 443447. doi:10.1093/rpd/nch409

Ohio Environmental Protection Agency (OEPA) (2005). Radionuclides in Public Drinking water. www.epa.state.oh.us (June, 2005)

Oni O. M., Farai I. P. and Awodugba A. O. (2011) Natural Radionuclide Concentrations and Radiological Impact Assessment of River Sediments of the Coastal Areas of Nigeria, Journal of Environmental Protection, 2011, 2, 418-423 doi: 10.4236/jep.2011.24047

Papastefanou C., Stoulos S. and Manolopculou M., (2005) The Radioactivity of Building Materials, Journal of Radio-analytical and Nuclear Chemistry, Vol. 266, No. 3, pp. 367-372. doi:10.1007/s10967-005-0918-z

United Nations Scientific Committee on Effects of Atomic Radiation (UNSCEAR) (1993) Sources and Effects of Ionizing Radiation, Annex A, New York.

United Nations Scientific Committee on Effects of Atomic Radiation (UNSCEAR), (2000) Sources and Effects of Ionizing Radiation, Annex B, New York.

Yang Y.X, Wu X.M, Jiang Z.Y, Wang W.X, Lu J.Gand and Lin J. (2005). Radioactivity concentration in soil of the Xinzhuang Granite Area, China. Appl. Radiat. Isotop. 63: 225-259. 